\title{
Old Age and Nostalgia in Nirmal Verma's Fictions
}

\author{
Akhil Puthiyadath Veetil \\ Manipal Centre for Philosophy and Humanities, Manipal University. \\ Email: akhil.veetil@gmail.com
}

Received August 10, 2017; Revised September 13, 2017; Accepted September 15, 2017; Published September $20,2017$.

\begin{abstract}
This article explores the theme of old age and attempts to understand whether nostalgia can be understood without reducing it to revivalism. Using Nirmal Verma's novel Antim Aranya and his short story "Pichli Garmiyon Mein", the article shows that Verma uses several literary techniques in order to suspend time and evoke contemplation albeit without providing any prescriptive conclusions. Furthermore, contemplation along with nostalgia is never presented by Verma as an attempt to recreate the past. On the contrary, nostalgia presented through old age acts as a critique of modernity and its interpretation of progress. Therefore, Verma's writings can be seen as an ethical stance against a future and goal-oriented framework, which alienates individuals from all generations.
\end{abstract}

Keywords: nostalgia, memory, Nirmal Verma, Hindi Literature

\section{Introduction}

While the theme of memory and loss can pertain to everyone including the young, it has become the norm to associate them with the aged. Having lived the longest in any society, the elderly are generally portrayed as backward-looking and nostalgic about an older way of life. While this may be true to some extent, it is also important to acknowledge the pitfalls of reducing nostalgia to a mere longing for the past. Nirmal Verma (1929-2005), a prominent Hindi writer, attempted to bring a nuanced understanding of nostalgia through his fictions. Verma was considered a prominent Hindi writer; his writings were characterized by their lyrical prose, melancholic exploration of alienation, and the inability to make sense of the rapid changes occurring in the urban spaces of the new nation. His politics and literary sensibilities were shaped by the World Wars, Partition violence and Soviet aggression in Eastern Europe, the aftermath of which he personally experienced during his long stay in Prague. As a result, his works tend to capture the emotions arising out of the psychological fragmentation of the individual as well as its implications on the family and inter-generational relationships.

Two questions are broadly explored in this essay: (1) what is the significance of old age and death in Verma's works, and (2) what new insights on nostalgia can emerge from such a reading of his fictions? Other than the question of memory, several other themes might emerge from looking back into one's past (but not necessarily living in one's past): themes which might be limited in a worldview that consistently aims towards the future at the cost of the past. These themes could include failure, regret, and even the role of closure during the last stages of one's

(C) AesthetixMS 2016. This Open Access article is published under a Creative Commons Attribution Non-Commercial 4.0 International License (http://creativecommons.org/licenses/by-nc/4.0/), which permits non-commercial re-use, distribution, and reproduction in any medium, provided the original work is properly cited. For citation use the DOI. For commercial re-use, please contact editor@rupkatha.com. 
life. Retrospection entails a mature and contemplative engagement with one's past where the attempt might be to make sense of one's life as a whole. Whether the individuals achieve those aims is a different question altogether. Nevertheless, the act of looking back and the questions posed by old age are worth considering-especially through the theme of nostalgia. The argument made in this essay is that Verma invokes nostalgia not to create a longing for the past, but as a tool to manipulate time and invoke contemplation. The implications are twofold: it becomes a way of critiquing a future-oriented notion of literature and politics as well as reinterpreting the past as not providing any prescriptive answers. Three arguments are made through the course of this paper: (1) Verma uses several literary techniques to suspend time and to evoke contemplation by creating images and conversations that linger and do not necessarily lead to a conclusion. (2) Nostalgia is never presented as an attempt to recreate or return to the past in any manner-the characters' relationship with the past is neither one to be avoided nor one to be cherished as a lost golden age. (3) Nostalgia for Verma is a representation of a "shared vulnerability" (Bonnet, 2010, p. 6) that both the old-aged and the youth experience. Two of Verma's works will be explored: the novel Antim Aranya (2004) and the short story "Pichli Garmiyon Mein" (1968). While there is historical relevance to how the question of old age has to be contextualised, this essay will be an attempt at understanding how Verma looks at old age as a larger category and not necessarily grounded in a local context.

\section{Antim Aranya and the Nature of Reminiscence}

Antim Aranya was Verma's last novel and is considered his deepest engagement with the question of death. While many writers wrote memoirs in the later stages of their lives, Verma appears to be writing about his personal experiences through the fictional characters of both the unnamed protagonist and more importantly Mehra sahib-a retired bureaucrat and widower. Some aspects of Mehra's life are quite similar to Verma's-two marriages where the second wife is significantly younger than Mehra. However, factual similarities are limited. The protagonist is a man in his late thirties who, facing a mid-life crisis, decides to take up the job of an informal caretaker of Mehra. His role in the new house is vague, often entailing being a listener and writing down anecdotes of Mehra's life. At times, the protagonist seems to be struggling with these anecdotes as he tries to construct a more holistic account of Mehra's life. Early in the novel, we notice the protagonist at a distance, observing Mehra while standing outside his house. The image keeps lingering and the entire observation is set at night, thereby lending it a liminal quality.

वह अचानक खड़े क्यों हो गए? वह दरवाज़ा खोलकर भीतर क्यों नहीं चले जाते? उन्होंने टॉर्च बुझा दी और बन्द कमरे के आगे देहरी पर ठिठके रहे। क्या वह कुछ सुन पा रहे हैं, जो इतनी दूर सै मैं नहीं सुन पाता? क्या यह ठीक है, इस तरह अपने घर के आगे चोरों की तरह खड़े होना, खुद अपने घर की आवाज़ों को सुनना? इस उम्र में क्या आदमी इतना शक्की हो जाता है कि स्वयं अपनी दीवारों पर सन्देह करने लगता है? (Antim Aranya, p. 9)

दो पहाड़ियों के फ्रेम में जड़ी उनकी कॉटेज अपने भीतर की रोशनियों में चमचमा रही थी। अँधेरा कहीं था तो सिर्फ़ वहाँ, जहाँ वह खड़े थे। अपनी झुकी हुई पीठ हिलती हुई छड़ी और बुझी हुई टॉर्च के साथ (Antim Aranya, p. 10)

Why has he suddenly stopped? Why doesn't he open the door and step inside? He puts out the torch and lingers awhile outside the closed door. Does he hear something, which I 
can't from a distance? Is it right to prowl about one's own house like this, eavesdropping? Does a man become so suspicious at his age as to become wary of his own?

Framed between two hills, his brightly-lit cottage shone like a jewel. If it was dark anywhere, it was the spot where he was standing. With his bent back, his quaking stick and his blind torch. (“Antim Aranya: 1.1”, p. 191)

These images neither establish the physical surroundings as a context nor assist in plot development. The description is given a poetic quality by suspending time and highlighting certain parts of the image. Furthermore, it manages to set the tone of the novel. The protagonist appears to be perplexed at Mehra's actions. What Verma captures here is not the actual act, as much as the meaning imbibed. The purpose is not to explain the setting, but to focus on the heightened sense of individualism that comes with old age. This needs some clarification. M. Elaine Cumming (1971) proposed the theory of disengagement while exploring the sociological patterns in the behaviours of the elderly. She states that the process of aging is accompanied by 'mutual withdrawal' between the aging person and other individuals within a community. This leads to less intimacy and a changed notion of solidarity with another individual (Cumming, 1971, p. 3). Furthermore, this argument carries literary significance as well. Mutual withdrawal from society also requires a reorientation towards several other aspects of one's life-the meaning of home, reconciliation with problems from the past or even the question of how to make sense of one's life. It is as if examining these questions implies looking into things previously taken for granted. This image of the individual standing in front of an empty house is repeated on several occasions in the novel. Anna, an old German woman, tells the protagonist of the satisfaction she gets while standing in front of her empty house (Verma, 2015, p. 31). However, her line of questioning leads to a different conclusion, which is relevant for this essay. This re-examining of one's home leads Anna to an imagination of the mountainous village as her home. However, she does not see the village as part or representative of India. Anna becomes an embodiment of the question of national identity and belonging. Despite being the oldest resident among all the characters, Anna is still seen as a foreigner by the protagonist. However, the detachment from a larger community-whether it be India or Germany-provides her the relief of giving home a meaning not routed through the nation. It is as if one aspect of old age, as mentioned above, is about reorienting one's solidarity. When the relationship between individuals and their societies change, solidarities are bound to be reconsidered as well. In the case of Anna, this change due to aging leads to a possibility of looking at home without any ideological affiliation to a larger community. Furthermore, she does not appear to propose any alternatives-leaving her home as merely a space of comfort stripped off identity politics. However, Verma is not ignoring the question of identities. It has been well established and argued that individuals carry multiple identities, which may include a form of territoriality. Ashis Nandy (2012) defines patriotism as an 'emotional state, bonding, or investment' in which one 'presumes the existence of communities other than the country and gives them due recognition, sometimes even priority'. On the other hand, nationalism is defined as 'a more specific, ideologically tinged, ardent form' of loving one's kind which relies on 'fearful dislike or positive hostility' towards outsiders (Nandy, 2012, p. 6). Verma's uniqueness lies in presenting the relevance of the past and thereby pausing a future oriented approach to literature. In other words, it is a question whether a future based on certainty-a secular, modern India-is capable of allowing space for those who choose to reimagine the community. This re-imagination has the potential to deviate from the more confined understanding of citizenry and national identity. However, Verma is careful not to reduce the alternative to an affirmative territoriality. On the contrary, it is the difficulty in placing Anna in the context of a national identity that destabilises preconceived notions. 
The novel continues with the protagonist regularly meeting other characters in the village. Occasionally, he is called by Mehra to pen down anecdotes of his life. The conversations between both of them become moments of personal exploration for the protagonist to the extent that the novel is ambiguous about whose story is central to the plot. For example, the following passage is one of the many encounters between the protagonist and Mehra:

और इस तरह पोथियाँ इकटा होने लगी, एक के बाद एक| न जर्नल, न डायरी, सिर्फ तिथियां, शहरों के नाम, यात्राएं, डाक-बंगले, नदियां नहरें, मानसून का महीना और बाढ़ क दिन... एक तरह की रिफरेन्स बुक...कुछ स्मृत्यों का मानचित्र, पीले कागज़ पर बिखरे शरणार्थी शहर, जिन्हे आपस में जोड़कर मैं उन पड़ावों के शरणस्थल अंकित करता था, जहाँ उनका जीवन बीता था। जब वह कुछ कहते रुक जाते, भटक जाते, भूल जाते, तोह मैं उनके सहारे उन्हें दुबारा लीक पर ले आता [...] मैं सोचता था, शायद वह किसी भूली हुई घटना को याद कर रहे हैं जबकी अक्सर होता यह था, वह किसी याद आई घटना को भुला देने की कोशिश कर रहे होते थे| याद आने और भूलने के बीच जो खाई आती थी, उससे बचने के लिए मुझसे पूछते थे, क्यों साहब, मैं कहाँ ठहरा था? (Antim Aranya, p. 16)

And soon, volumes of books were being stacked, one after another. Neither a journal, nor a diary, only dates, names of cities, travels, post-offices, rivers, monsoon and the days of floods...a kind of reference book...a map of memories, scattered refugee cities on yellow paper, which I put together to understand the shelters where his life was spent. After saying something when he pauses, wanders, forgets, I use these references to bring him back. [...] I used to think, maybe he is remembering a forgotten moment, whereas in reality, he was trying to forget a remembered event. To escape from the gulf between remembering and forgetting, he's ask me, sahib, where did I pause?

The protagonist is experiencing a midlife crisis and is writing down accounts of an old-aged man. While Mehra organically moves from one memory to another, the protagonist is initially concerned with bringing Mehra back on a single track. This point can be explicated using Kirsten Jacobson's (2016) essay on the phenomenological perspective of dying. Jacobsen argues that death is not the end of reality, but an end of the capacity for letting the world matter. Using Heidegger, she further suggests that anxiety is a result of emptiness and that fear of death is an attempt to avoid facing this anxiety (Jacobson, 2016, p. 77-78). We only speak about death as facts, but never about another aspect of death, which is our inability to reflect on our own death-that 'the meaning of death is precisely the death of meaning' (ibid, 85). While the protagonist tries to bring Mehra back on track, his approach consists of a more linear retelling of one's past, as if the aim is to eventually reach the present and proceed to the future. Perhaps the most striking aspect of this passage is the conflict between two worldviews. While Mehra is working within the framework of remembering and forgetting, the protagonist who is in charge of recording Mehra's past, wants to remain on a goal oriented progression. Robert Butler's (1971) proposed term 'Life Review' will help in clarifying this argument. Life Review is the return to and re-examining of unresolved past experiences prompted by the realisation of impending death. This reminiscence however, at the same time, obscures awareness of the present realities (Butler, 1971, p. 266). The concept of life review is used here to counter the claims of reminiscence being a cause of obscurity. Mehra's character is not moving away from present realities, but is departing from the tendency to discard the past. Reminiscence is not the obscuring of present realities, but a more complex awareness of the relevance of the past in one's present. This perspective is further emphasised in old age since 
the act of looking back comes with the realisation that there is little to look forward to. Whatever there is to look forward to, carries little hope and therefore Antim Aranya is not capable of (and does not intend to) become emancipatory for two reasons: first, that death is the end of a future, and second, that death is a highly individualistic experience. While everyone experiences death, one always remains unique since death happens to that person only once. Therefore, one can see how Verma's old-aged individual stands opposed to an imagination of the collective future by repeatedly reminiscing the past. As a result, one can see a subtle transformation occurring in the text. The protagonist slowly begins to see value in Mehra's silences, which is evident in the following passage.

अकेले में क्या करते होंगे, कोई ऐसे आस्थावान भी नहीं की पूजा-पाठ करते हों| ईशवर, मृत्यु, पुनर्जन्म...कभी तो सोचते होंगे? शायद सोचते हों...मुझसे कभी चर्चा नहीं करते थे| बाउंड्री के बाहर छोड़ देते होंगे, जैसे कुछ घरों के बाहर पुरानी चिट्डियाँ फेंकी जाती हैं, जिनमे घर के भेद और मन की व्यथाएँ दबी होती हैं। एक दिन कोई आता है, सब बुहारकर ले जाता है| कुछ भी बचा नहीं रहता. बढ़ती उम्र के खाली पिछवाड़े| (Antim Aranya, p. 40)

I wonder what he does alone, there isn't even any setup for him to pray. God, death, rebirth...he must have thought about these? Maybe he does think...he never tells me. Leaves me outside the boundary, like how in some houses old letters are thrown out, in which domestic troubles and mental pain are pressed in. One day someone will come and take all of them away. Nothing remains behind. Ageing and its empty backyard.

The transition leads to the protagonist reorienting himself. While it is Mehra who remains silent and is being reminiscent, the protagonist is now contemplating the contents and the purpose retrospection. These lingering thoughts are a break from the linearity and 'progression' that is associated with social realism. Contemplation here does not lead to a significant change in the future-the novel does not give the readers an account of the future. Nevertheless, it acts as a critique of a system of thought which discards the past.

\section{The transition from recording silences to finding value in the past}

As the novel proceeds, the protagonist continues to see changes in his perception and understanding of the world. However, the frame of reference is Mehra. At times, Mehra talks about his past, which moves beyond factual accounts. He briefly mentions the death of his first wife and regrets not helping Deeva (second wife) end her life sooner. The transition is brief and momentary, but Verma's attempt in the novel is to give depth to such moments. In these brief moments, where the past becomes more than facts, there is a sense of regret, but it does not get reduced to either a discarding of the past or it being recreated. Three excerpts are provided below to show the evolution of the novel from describing silences to examining its content and implications. In the following passage, Niranjan, an old friend of the protagonist, talks to him about his family in Jaipur and his tendency to temporarily escape from his family in the apple orchards of the mountainous village.

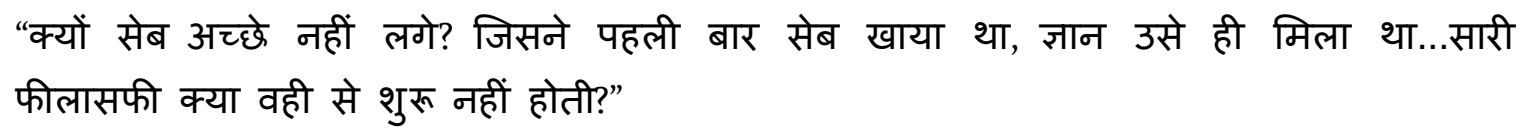

"अगर ज्ञान ऐसे आता है, तो यहाँ राह क्यों नहीं जाते?" मैंने कहा 
"में तुम्हारे तरह अकेला नहीं हूँ, न पत्नी, न बच्चे...हर सुख का मूल्य चुकाना पड़ता है" "परिवार का सुख, दुनिया में रहने का सुख....आदमी क्या सारी मारकाट इन सुखों के लिए नहीं करता?" (Ibid, p. 62)

“Didn't you like the apples? The one who first ate the apple gained knowledge...doesn't all of philosophy begin from there?"

"If that's how knowledge is gained, then why don't you remain here?" I asked

"I'm not alone like you, no wife, no children...there is a price to pay for every happiness!"

"Happiness having a family, living in this world...aren't humans violent to gain these joys?"

"यहाँ कम से कम यह संतोष तो रहता है की अपने को धोखा नहीं दे रहा. वैसे भी सुबह से शाम तक इतना काम रहता है की अपने बारे में सोचने को एक पल नहीं मिल पाता|

आग की पीली लपटों में उनका चेहरा थका, क्लांत-सा जान पड़ता था, हालाँकि उम्र में वह मुझसे कुछ ही साल बड़े थे| पुराने दोस्तों के चेहरे खुद हमें अपने होने के खंडहरों की याद दिलाते हैं...चेहरे की झुर्रियां, सफेद होते बाल, माथे पर खिंची त्योरियों के गली-कूचे... जिनके चौराहों पर हम उन्हें नहीं, खुद अपनी गुज़री हुई ज़िन्दगी के प्रेतों से मुलाकात कर लेते हैं. (Ibid, p. 65)

"At least there is the satisfaction here that I'm not cheating on myself. And besides, there is so much work the whole day that I don't get time to think about myself." [Niranjan said]

His face appeared jaded and tired in the light of the fire, even though he's only a few years older than me. Faces of our old friends reminds us of our existence...wrinkles on the face, whitening hair, lines and alleys drawn on the forehead...where we don't see them, but meet the ghosts of past.

By interpreting Ahmed Ali's Twilight in Delhi (1940), Anjaria (2011) argues for a more flexible understanding of social realism or pragatisheel literature that is capable of showing the limitations of realism and preventing social realism from being reduced to mimesis (Anjaria, 2o11, p. 188). In other words, realism also has the potential to break linear narratives. Anjaria explains elements of theatre in Twilight in Delhi. The novel is set around the theme of the decline of Old Delhi and rise of New Delhi in 1911. It is the story of the larger decline of Islam in India. Anjaria asserts that nostalgia becomes a performative aspect of the novel-as if it is theatrical-in order to gain access to a past that has been cordoned off (ibid, p. 190). However, it entails a sense of being a parody since there is an awareness of the inability to access the past. Mir Nihal, the protagonist of the novel, seems to be enraged by the injustice of the British rule which led to the demise of the Mughals. While he sees images of Old Delhi's grandeur flash before his eyes, he calls his grandson, Nasim, and seeks a promise. Mir Nihal hopes that Nasim will one day fight the British, implying a return to Mughal glories as well as an imagination of the future of India which is not necessarily within the framework of the nation-state (ibid, p. 198). Verma's writing, taking the two passages above as an example, is a continuation of this flexibility that Twilight in Delhi provides, yet at the same time, it does something different. First, there is no imagination of the grandeur of the past. This is also because while Mir Nihal is an old man looking back at the lost past, his suffering arises out of the loss of a larger community or empire. In other words, he stands as a representation or metonymy for the demise of an entire community. On the other hand, Verma's characters are highly individualistic and are difficult to be reduced to a representation of 
a community. Second, Twilight in Delhi uses nostalgia and reminiscence with the hope that the future generation could restore order and ensure justice. While Ahmed Ali was criticised by the AIPWA for being nostalgic, another perspective will help us find the underlying patterns in both the Marxist social realism of AIPWA and Ahmed Ali's approach. Rajendra Yadav and K.A. Abbas (1975) explain how social realism carries a rationalist tendency and therefore the aim should be to move away from the superstitious and communalist past with the aims of emancipation (Abbas, 1975, p. 145). Ahmed Ali's novel also looks into the future, albeit with the hopes of bringing back Mughal glories. On the contrary, Verma's characters never appear to have any proposal for the future. His novels use nostalgia and reminiscence as a mode of self-reflexivity, which resists the progressive and future-oriented notions of AIPWA. Niranjan acknowledges the complexities of desires in which attaining happiness of any kind comes with a cost. This prevents the past from being dismissed or romanticised, and highlights themes such as failure and regret. This is also why when the protagonist looks at Niranjan, he suddenly and consciously reflects on his own existence and his tendency to escape from such nuances which are not necessarily about justice or progress. Perhaps the clearest indication of this nuance is visible when the protagonist manages to grasp the contents of retrospection.

मेहरा साहब कुछ भी नही समझ पाते| लगता है, जो अब तक समय था, एक बैसाखी, जिसके सहारे इतनी चढाई पार कर ली थी| अब नीचे झांककर देखते हैं, तोह अपनी कमाई नहीं, दूसरों के कष्ट दिखाई देते हैं...हर कष्ट जैसे पत्थर हो, जिस पर पांव रखते ही कोई चीख सुनाई देती है....और वह जल्दी से पैर उठा लेते हैं...क्या फायदा है, अपने पैरों के निशानों पर दुबारा चलने का? (Antim Aranya, p. 131)

Mehra sahib couldn't understand anything. It seems as if time so far, is a crutch support, which he used to cross so many steps. Now when he looks down, he doesn't see his earnings, but the sufferings of others...as if every suffering is a stone, on which when a foot is kept, one can hear someone's scream...and he quickly removes his foot...what's the purpose of walking back on one's footprints?

Alistair Bonnet explains the relevance of nostalgia by suggesting that nostalgia is denied the kind of complexities which other emotional states are given. For him, nostalgia is not to be brought back, but to be acknowledged as an existing and integral part of human beings. He provides a distinction between ancient and modern nostalgia. Ancient nostalgia was largely associated with the origin story and a golden age from which the community emerged. As a result, it is considered to be a characteristic shared by several cultures. However, modernity is considered to be a faster and far reaching change, which made the relationship with loss significantly more intense (Bonnet, 2010, p. 20). This radical change became more rapid when nature ceased to have constraints on human beings and uprooting became a common phenomenon in modern societies. The disturbances in the notions of past resulted in perceiving nostalgia or reminiscence as an obstacle towards a reformed society. On the other hand, Verma chooses to examine what is remembered when one looks at the past and the metaphor of stepping stones in the previous passage brings out these nuances of Verma's intellectual viewpoint. Verma isn't opposed to the notion of reforms or emancipation. His discontent arises from discarding the past as if it is a separate entity. What remembering does is that it allows one to retrospect and understand the cost that enables an individual to 'progress'. But this is only possible if Verma manages to suspend progression in the novel itself by pausing and providing depth to momentary thoughts. In many ways, the mountains are apt for pauses, where the individual can feel isolated from the society 
physically. The novel ends with Mehra's death. The protagonist takes his ashes to a river downhill wondering how to make sense of his life spent in this remote, quiet and picturesque village.

\section{Old Age and the fragmented family: Analysing "Pichli Garmiyon Mein"}

"Pichli Garmiyon Mein" is a short story situated in Delhi in the 196o's. The protagonist works in Vienna and has returned to Delhi to spend time with his parents during his holidays, and the story takes place during the last few days of his holidays before his return. His younger brother is in the Army while his sister is married and lives separately in Delhi. There is a brief hint at a possible relationship between the protagonist and a girl in Delhi, while the story also reveals his live-in relationship with a woman in Vienna. What is interesting in this short story is the gap that exists between the son and his parents, which takes place in the context of a dispersed family. This text can be interpreted as an example of the fragmented middle class family and how Verma attempts to capture the gap between the younger and older generations. In this case, the protagonist appears to lead a disoriented life due to the inability to communicate with his parents. The protagonist has dinner with his parents, which Verma describes with a mood of awkwardness and uncomfortable conversations.

वह कभी न समझ पाते थे, इन तीन वर्षों के अंतराल के बाद कैसे बात की जाये.

खाने की बात सुनकर माँ कहती, "अच्छा, नीता कहती थी, वहां मांस-मच्छी के सिवा कुछ मिलता नहीं..क्यों?"

अभी वह जवाब नहीं दे पाया होता था कि बाबू पूछते, "अच्छा सर्दी तो वहां काफी पड़ती होगी?"

"हाँ लेकिन कमरे में सेंट्रल हीटिंग रहती है. भीतर पता नहीं चलता." वह धीरे-धीरे कहता.

माँ उठकर अपने कमरे में चली जाती| घर में एक बोझिल-सा सन्नाटा घिर आता| वह प्रतीक्षा करता| उसे लगता, बाबू उससे कुछ कहेंगे| बहार अगस्त की गर्मी और उजली रात सिमट आती| बाबू कुछ न कहते और अपलक उसकी और देखते रहते| बगलों की पास उसकी कमीज पसीने से तर हो जाती| वह भीतर-ही-भीतर प्रार्थना करता रहता कि वह कुछ कह दे जिससे बरसों से खिंचा यह अजीब-सा तनाव टूट सके| किन्तु आखिरी छोर पर आकर सहसा बाबू इरादा बदल देते हैं। ("Pichli Garmiyon Mein”, p. 148)

They never knew [parents], after this gap of three years, how to talk to him.

Listening to the conversation on food mother said, "Neeta said you don't get anything there except meat and fish...is that true?"

Before he could answer the question, father would ask, "It must get really cold there?"

"Yes, but there is central heating. You don't feel it inside." He would say slowly.

Mother would get up and go to her room. There would be a cumbersome silence. He would wait. He thought father wanted to say something to him. August heat and darkness would come inside. Father wouldn't say anything and without blinking, would keep looking at him. His shirt near the armpits would be wet with sweat. He would keep hoping inside that father would say something that would break the prolonged and strange tension. But at the very last moment, suddenly father would change his mind. 
Yet again we see Verma portraying intensity to a dinner conversation and as a result, evoking strong emotions. However, this story is different from Antim Aranya because the theme is an encounter between family members, and more importantly, set within an urban household. The setting of the story is similar to Bhisham Sahni's "Chief ki Dawat", but while Bhisham Sahni tries to show the disregard for the elderly in a highly materialistic society, Verma doesn't suggest such a clear distinction between the perpetrator and the victim. He prefers to show the gap in understanding between two generations, making both of them appear as victims of a broken family. It is the broken interpersonal relationship that Verma highlights. The dinner table becomes a metaphor for the lack of meaning that emerges from relations. Shanon Hoff (2016) explains how a sense of belonging and meaning making emerges from inter-subjectivity. Therefore, taking away this inter-subjective foundation of identity could result in a 'pain of exclusion' (Hoff, 2016, p. 219). A highly individualistic society tends to under-acknowledge this pain. Liberalism works on the belief that individuals must be left unimpeded to pursue their conceptions of good life' (Bilgrami, 2016, p. 176). The interaction between the protagonist and the father reveals the vulnerability of old age, since the pursuit of a good life for the discrete individual leaves little space or support for those who rely on intersubjective meaning. For example, later in the story, the protagonist suddenly realises how old and weak his father has become. When his father asks him to stay back for a few more days, the protagonist finds it difficult to connect to the family he migrated away from three years ago. However, Verma does not depict the protagonist as a successful or ambitious son of "Chief ki Dawat", but as an equally vulnerable character. The father stands as a metaphor for the larger question of how to provide voice to old age, which consists of the lived experience of alienation, vulnerability and being a witness to changes happening to a society that chooses to discard the past. In a society where youth is privileged over old age, Verma uses the older characters as a lingering reminder to a society that only looks towards the future. His success lies in making this question explicit with the use of craft, in order to give rise to the strong raw emotions that are associated with a sense of abandonment. Furthermore the larger social reality has made both the father and the son equally vulnerable where the solution cannot be revivalism or reformation. As in the case with Mehra in Antim Aranya, Verma merely leaves us with underlying problems of his contemporary society and in a difficult space of uncertainty. The readers must engage with the questions themselves, as the two protagonists do.

\section{Note}

i This in reference to Akeel Bilgrami's Beyond the Secular West, where he describes modernity as the shift from (1) nature to natural resources, (2) human beings to citizens and (3) people to populations.

\section{References}

Abbas, K. A. (1975). Khwaja Ahmad Abbas. In S. Kohli (Ed.), Aspects of Indian Literature (pp. 145-154). New Delhi: Vikas Publishing House.

Anjaria, U. (2011). Staging Realism and the Ambivalence of Nationalism. NOVEL: A Forum on Fiction, 44(2), 186-207. doi:10.1215/00295132-1260950

Bilgrami, A. (2016). Beyond the Secular West. New York: Columbia University Press. 
Bilgrami, A. (2016). Secularism and Relativism. Boundary 2, 31(2), 173-196. Retrieved from https://muse.jhu.edu/article/171409.

Bonnett, A. (2010). Left in the Past: Radicalism and the Politics of Nostalgia. London: Continuum.

Butler, R. (1971). The Life Review: An Interpretation of Reminiscence in the Aged. In R. Kastenbaum (Ed.), New Thoughts on Old Age (pp. 265-280). New York: Springer Science Business Media

Cumming, M. (1971). New thoughts on the theory of disengagement. In R. Kastenbaum (Ed.), New Thoughts on Old Age (pp. 3-18). New York: Springer Science Business Media.

Hoff, S. (n.d.). Pain and Agency: On the Essential Importance of Vulnerability and Transgression. In P. Jung \& S. K. George (Eds.), Cultural Ontology of the Self in Pain (pp. 211-233). New Delhi, 2016: Springer

Jacobson, K. (n.d.). Waiting to Speak: A Phenomenological Perspective on Our Silence Around Dying. In P. Jung \& S. K. George (Eds.), Cultural Ontology of the Self in Pain (pp. 75-92). New Delhi, 2016: Springer.

.Nandy, A. (2012). Nationalism, Genuine and Spurious: A Very Late Obituary of Two Early Postnationalist Strains in India. Occasions: Interdisciplinary Studies in the Humanities, 3, 1-10. Retrieved from http://occasion.stanford.edu/node/105

Raja, I. (2001). Antim Aranya: 1.1. Indian Literature, 45(5), 190-195. Retrieved from http://www.jstor.org/stable/23344668

Verma, N. (2015). Antim Aranya. New Delhi: Bharatiya Jnanpith.

Verma, N. (2001). Pichli Garmiyon Mein. In Pratinidhi Kahaniya. New Delhi: Rajkamal Prakashan.

Akhil Puthiyadath Veetil completed his Masters in English from the Manipal Centre for Philosophy and Humanities, Manipal University in 2017. His thesis examined the role of uncertainty in Nirmal Verma's fictions. 